\title{
Risk Management of Bored Piling Construction on Sandy Soils with Real-Time Cost Control
}

\author{
Pedro Mata ${ }^{1, *}$, Paula F. Silva ${ }^{1}(\mathbb{D})$ and Fernando F. S. Pinho ${ }^{2} \mathbb{D}$ \\ 1 GeoBioTec, Department of Earth Sciences, NOVA School of Science and Technology, FCT Nova, \\ NOVA University of Lisbon, Campus de Caparica, 2829-516 Caparica, Portugal; apfs@fct.unl.pt \\ 2 CERIS, Department of Civil Engineering, NOVA School of Science and Technology, FCT Nova, \\ NOVA University of Lisbon, Campus de Caparica, 2829-516 Caparica, Portugal; ffp@fct.unl.pt \\ * Correspondence: a6270@campus.fct.unl.pt
}

check for updates

Citation: Mata, P.; Silva, P.F.; Pinho, F.F.S. Risk Management of Bored Piling Construction on Sandy Soils with Real-Time Cost Control. Infrastructures 2021, 6, 77. https:/ / doi.org/10.3390/infrastructures6050077

Academic Editors: S. Sonny Kim,

Jongwan Eun and Soonkie Nam

Received: 14 April 2021

Accepted: 17 May 2021

Published: 20 May 2021

Publisher's Note: MDPI stays neutral with regard to jurisdictional claims in published maps and institutional affiliations.

Copyright: (c) 2021 by the authors. Licensee MDPI, Basel, Switzerland. This article is an open access article distributed under the terms and conditions of the Creative Commons Attribution (CC BY) license (https:// creativecommons.org/licenses/by/ $4.0 /)$.

\begin{abstract}
In a global society, in which geotechnical projects are increasingly designed in a country other than the one where construction takes place, geotechnical risk management must be extended to cover infrastructure works, which are smaller than dams and tunnels, for example, since there is a significant impact on works budget imponderables. Therefore, a risk management methodology based on the likelihood of the occurrence of certain events and their economic consequences is proposed, which is applicable to bored piles (Kelly drilled) in coarse soils, easy to use, and simple to implement since the initial stage of construction. Of 12 case studies of construction works involving bored piles (Kelly drilled) carried out in Luanda (Angola), two selected examples involving the proposed risk methodology on sandy soil layers with interbedded clays are discussed. Subsequently, whether the overall foundation contract budget is affected by assessed risk is determined, and what influence it has on the budget in the light of mitigating factors and associated real costs. This method intended to encourage the adaptation of sustainable risk management in bored piles construction by the site project managers, involving risk analysis concurrently with budgetary review. Though the level of assessed technical risk may be acceptable, overall costs associated with the contract in question may not be acceptable.
\end{abstract}

Keywords: risk management; bored piling; Kelly drilled; sandy soils; construction stage; activitybased costing $(\mathrm{ABC})$

\section{Introduction}

To achieve a sustainable building process, a rigorous economic and technical analysis is required in all design steps. One of the most widely used tools in geotechnics field consists of management of risks associated with a project, including the construction stage. Since the $90^{\prime}$ s of the 20th century, designers, contractors, and contracting organizations started to adopt risk management in large-scale construction structures, to avoid delays and budgets deviations and to reduce the associated insurance costs of which a large portion of it is generally allocated to the construction of deep piling [1], required to cover geological/geotechnical (hereafter referred to as geological), technical and human risks [2-6].

Nevertheless, there is still a disparity in the implementation of this tool between the design [7-9] and operational stages [2] for less technical complexity projects as foundations infrastructures, in contrast to large-scale structures [3,10,11], like dams [12] or tunnels $[13,14]$. While excavated piling works involving bored piles are usually regarded as less important construction works, they account for a huge portion of the overall special (deep) foundations costs. This is made worse in developing countries due to a lack of specialized human and technical resources, with projects being carried out that have often been designed in a different country, while the conduct of risk management at the construction stage is still comparatively rare [15]. In small-scale projects, managers and designers 
are often not aware of the potential hazards at the construction stage. Most technicians are unaware of the economic risks of the project or how they both relate. Ahmed et al. [16] report that excavation projects risks cannot be evaluated only by systematic engineering calculations, which also applies to the construction of deep foundations and the associated decision-making should be promptly implemented.

Chapman [4] found that about $20 \%$ of delays experienced in deep foundations works in London were due to ground problems, $41 \%$ of which in the construction stage and $57 \%$ at the operational stage. Since some of such delays were due to inadequate project design and/or poor execution, risk analysis at the construction stage could significantly reduce problems that may arise at the operational stage. It is assumed by most designers that, although the level of uncertainty of a geotechnical project is significant, it may be acceptable, often leaving the contractor to adapt the project to real on-site conditions. The aim of risk analysis is to support the decision-making process, providing plausible scenarios [11] and is part of the rational management of economic, natural, human and technical resources, backing the need for risk management at the construction stage of deep foundations [17]. Stuedlein and Reddy [8] address the risk of performing piles, as well as their quantification through reliability models based on tests and limit states. However, despite considering the risk in construction, this study focuses on the consequences at operational stage but not at the piling construction. Bles et al. [7] refer to risks and events that may occur at design and construction stages, emphasizing the lack of a structured plan to their approach. Gransberg et al. [18] analyze the risk associated with foundations, from the contractor and the contracting authorities angle, comparing their risk profiles, advantages and limitations of this approach. Though Gransberg et al. [18] approach the theme at construction stage, they do not analyzed it from the economic perspective of the site project manager. The manager must also deal with risks to safeguard the sustainability of the deep foundation project while maintaining a constant interaction between the concepts of economic vulnerability, hazard, consequence and risk [11].

It is therefore essential that site project managers are provided with the tools they need to make effective decisions and that they know the factors that affect safety and costs. Risk management at the construction stage of deep foundation works [19-22], mostly involving bored piles $[5,6,23,24]$, is not yet widely conducted, even less so in conjunction with the management of the cost of individual activities (activity-based costing-ABC), as defined by Cooper and Kaplan [25]. This is mainly due to: (i) the low economic value of deep foundations as compared with other types of engineering works, where risk management is already conducted at this stage, and (ii) the short duration of piling construction stage. The use of site works risk management may increase value to the stakeholder, as suggested by Räikkönen [26].

Considering the above, the relevance of geological, technical and human risks management, at the piles construction process, and its interaction with real-time cost control is necessary by assessing: (i) what is "acceptable" [10,27], according to the existing knowledge of the site work context; and (ii) the different costs-benefits for each potential measure, to mitigate unacceptable risks that could support the decision making of whether to mitigate or incur those risks [28].

In this context and considering ISO 31000 [29] definitions of risk, stakeholder, event, consequence and likelihood, a risk management methodology is presented to be used at the construction stage of bored piles in sands, using the Kelly technique and a semiquantitative method for risk evaluation. The objective is to use an easy management that the construction team, particularly the site project manager, can implement at the construction stage. To test the proposed methodology, two case studies are presented. These studies are part of a larger research that includes a set of 12 case studies, involving a total of $48,061 \mathrm{~m}$ of bored piles in sandy soils with interbedded clays (with less than $1 \mathrm{~m}$ of thickness), above the groundwater level and in a nonseismic region. The methodology was implemented on-site, at those works, whether at the beginning or along the construction 
stage, by the first author, who managed them all with a clear improvement in both technical and financial performances.

\section{Risk Associated with Bored Piles Construction}

The risk management presented hereafter is carried out through two approaches normally separated at piling work sites: the technical angle and the economic angle. Nevertheless, in the end, both approaches become construction costs. The associated risks to be dealt with by both these perspectives have potential joint hazards that may be geological, human, or technical.

Often technicians (site project managers) and managers (company executives) have different approaches about the subject. The managers deal with the economic aspect through financing contracts [30] while technicians take care of the construction planning and management. As projects are executed aiming the return on invested capital, contributing to the sustainability of companies and resources involved as well as the development of a sustainable economy, both technicians and managers must collaborate at risk management of a geotechnical project, particularly at the construction stage, to achieve a technicaleconomical return that is financially sustainable and measurable, making it imperative to make decisions properly, easily and rapidly [31]. On the ongoing construction stage, risk management must integrate mitigating and/or corrective measures in case of an event manifestation; this will allow for the immediate execution, due to the reduced time available. However, these measures should be designed and prepared specifically for each project [21,32].

After the delivery of the bored pile project to the operation team, all the elements of the project (contract, tender budget and planning, and geotechnical report) should be reviewed and analyzed reinforcing the inspection of the tender budget and the premises that certify it. Next, the construction plan, production budget and risk management plan should be drawn up. These documents are interdependent as presented in Figure 1.

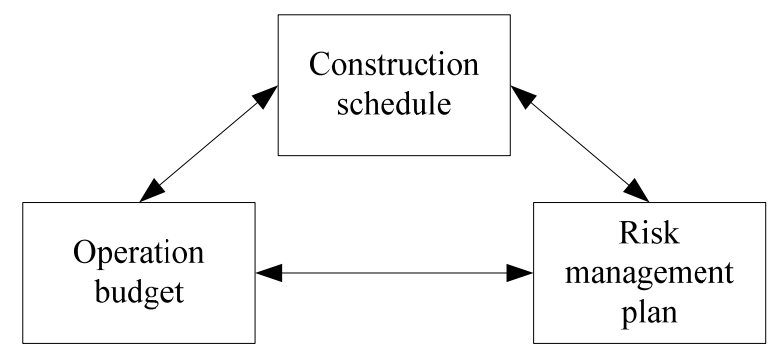

Figure 1. Interdependence between planning, budget and risk management at the construction stage.

The construction plan influences the budget, as supplementary execution time would involve additional costs, as well as for the risk management plan, where additional construction time would imply further likelihood of hazard exposure, while different construction techniques correspond to different hazards. The risk management plan influences the construction plan: to eliminate or mitigate a risk, one may have to change the production timetable and the budget. The budget limits both construction plan (as it may have to be accelerated to be accomplish) as well as the risk management plan, because in most of the pile projects, this risk plan is not considered in the tendering budget.

The site team usually analyze the operations budget whose content only has significance for the accounting management. It is not usually binding on the decision-making process at construction, and it is only relevant after a certain event that produced a certain cost; this is due to the lack of a risk management plan. Thus, it will be necessary to consider the budget and its interaction with the risk management plan, as it can provide the justification for an acceptable risk for a single pile to be mitigated at the construction stage when considering the total piling to execute.

Construction re-budgets are specific to each company, as they must be comparable with analytical accounting, which aims to know: (i) the costs of the activity; (ii) the weight 
in the company's balance sheet; (iii) to plan, control, and forecast spending and revenues and understand the expected results.

This way, construction re-budgeting and analytical accounting must have the same accounting premises, for managing both the cost, profit, or investment. The costs should be obtained by $\mathrm{ABC}$ [25] because only in this way can one perceive what are the nature of the costs that influence each construction activity (for example, to know the value of each material in concreting). Simultaneously at the construction stage, an easy and quick to use risk management plan must be implemented, based upon possible real costs and/or investments; both must be assessed - the cost is permanently integrated on site construction budget and the investment will contribute for the company's assets, usually being accounted for as a rental applied to the site by using such asset.

The tendering team must also use $\mathrm{ABC}$ as defined by the company accounting considering the simplifications of Kaplan and Anderson [33] to be comparable with construction budgets and allow a direct view of economic deviations. Part of the risk analysis at the construction stage should be defined and implemented by the site project manager.

\section{Proposed Methodology and Its Justification}

The proposed methodology (Figure 2) is to be applied on site either at the beginning or during the development of the construction works.

The procedure starts with hazard identification that includes the main potential hazards that might be encountered in soils at bored piling construction sites. According to the research carried out, events were analyzed in 117,657 m of piles in coarse soils in Angola, all coordinated by the first author, and the potential hazards sources of damages at the construction stage of bored piles with casing or bentonite support fluids were assembled according to the following typologies:

- Geological hazards: as a potential source of consequences, the uncertainties of the geological environment have significant implications for construction. If there are enough small variations in lithology or groundwater level not considered in the project, it can lead to the rethink of the entire construction process and the need to review the project. Adequate site investigation is the best way to avoid them; however, it is important to define the acceptable cost for the information obtained. Nevertheless, imponderable situations, intrinsic to geology, may still happen because it is not affordable to have a survey at each pile to be built [17];

- Human hazards: events that have as a potential source of damage to the works the site operatives. Their training and skills are relevant for the construction of foundationsfor example, continuous education and training for operatives directly or indirectly involved at works is key to the successful use of bentonite suspensions. Local culture directly influences productivity and the acceptability of risks [34,35], so it is necessary to know local customs to maximize productivity. Human error was not considered, as in the case studies consulted it was not identified so their associated likelihood is too low or null;

- Technical hazards: events that have as a potential source of consequence the inadequacy or incapacity of the equipment. The availability of equipment is conditioned by the resources of the contracting company, but also by geographical location because it is possible that a company may have the necessary means, but they are not available locally.

For each technical, geological, and human risk detected related to the soils and construction techniques identified in those thousands of meters of built piles, it was evaluated the associated likelihood and assessed their inherent damages, that is their financial impact, according to the percentage of the construction cost. 


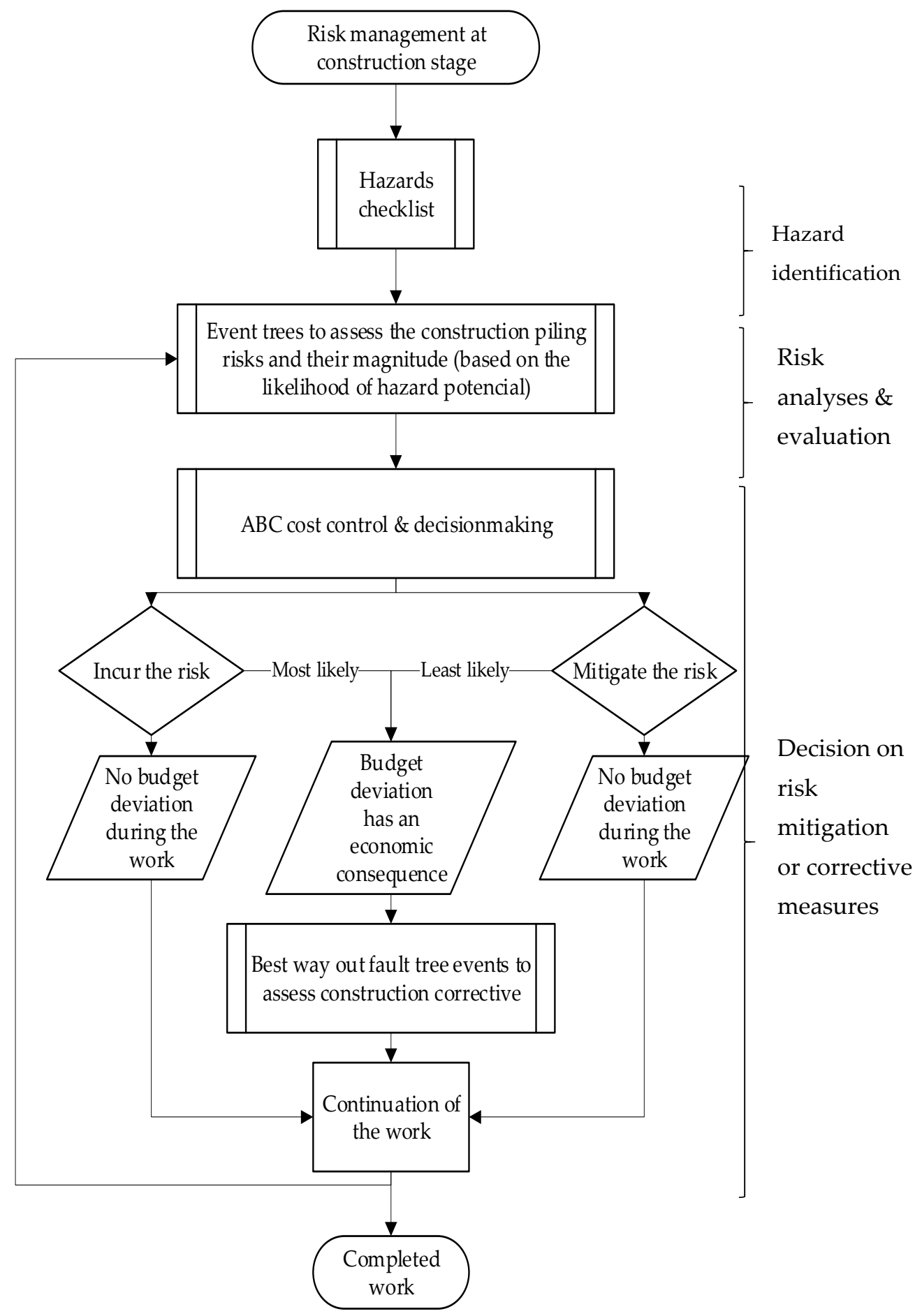

Figure 2. Schematic for risk management procedure at construction stage of bored piles (Kelly method).

With these elements and information from accounting a few checklists where elaborated. One for the identification of potential common hazards of bored piles (Kelly method) (Table 1) and two other for the specific hazards of piles using bentonite fluids (Table 2) and piles with casing (Table 3). These are exemplificative models; each technician should adapt them and make their own for the site and company where the work would take place, namely with the help of other experts from his/her company. Ideally, these checklists should be applied after the preparation of the site for foundation works and pile positioning and reviewed while drilling the first pile. 
Table 1. Example of common hazards checklist at construction of bored piles (Kelly method).

\begin{tabular}{|c|c|c|c|}
\hline & Hazards & Yes/No & N/A \\
\hline \multirow{11}{*}{ 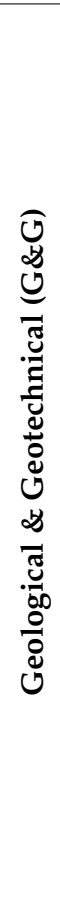 } & Are there, visibly, constraints to the execution of the work? & & \\
\hline & Does the geotechnical report exist, and is it accessible? & & \\
\hline & $\begin{array}{l}\text { Does the project replicate the characteristics of the ground } \\
\text { identified in the geotechnical report and confirmed on site? }\end{array}$ & & \\
\hline & $\begin{array}{l}\text { Does the drilled ground correspond to those listed in the } \\
\text { geotechnical report? }\end{array}$ & & \\
\hline & $\begin{array}{l}\text { Are there any gravels, cobbles, cimmented layers or blocks at the } \\
\text { ground? }\end{array}$ & & \\
\hline & $\begin{array}{l}\text { Do the contacts with the foundation layer present any known } \\
\text { irregularity? }\end{array}$ & & \\
\hline & $\begin{array}{l}\text { Does the drilling reached the projected depth for the foundation } \\
\text { layer? }\end{array}$ & & \\
\hline & Does the project mention a groundwater table? & & \\
\hline & $\begin{array}{l}\text { If so, is the groundwater level in accordance with the geotechnical } \\
\text { report? }\end{array}$ & & \\
\hline & $\begin{array}{l}\text { Is there a variation in the groundwater table while pile } \\
\text { construction? }\end{array}$ & & \\
\hline & $\begin{array}{l}\text { Is it possible to comply with regulatory or design tolerances, in the } \\
\text { case of more restrictive ones? }\end{array}$ & & \\
\hline \multirow{9}{*}{ 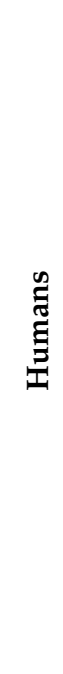 } & Do the site operatives have the basic needs of life met? & & \\
\hline & $\begin{array}{l}\text { Is there a Health and Safety Plan implemented on site applied to } \\
\text { the foundations construction? }\end{array}$ & & \\
\hline & $\begin{array}{l}\text { Do the site operatives have a specific Health and Safety plan at } \\
\text { work (HSW) training for the work to be carried out? }\end{array}$ & & \\
\hline & Does the site operatives team have the right size? & & \\
\hline & Are equipment operators duly qualified to use it? & & \\
\hline & $\begin{array}{l}\text { Is there a permanent technician on site who can interpret the } \\
\text { project and the geotechnical report? }\end{array}$ & & \\
\hline & $\begin{array}{l}\text { Is there a technician on site with knowledge of cost control } \\
\text { techniques? }\end{array}$ & & \\
\hline & Is shift work planned? & & \\
\hline & $\begin{array}{l}\text { Is the team able to extend working hours in case it is necessary to } \\
\text { finish a pile? }\end{array}$ & & \\
\hline \multirow{7}{*}{ 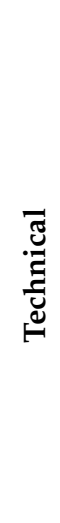 } & Is the intersection of anthropic structures planned in the project? & & \\
\hline & $\begin{array}{l}\text { If there are anthropic structures, are they identified and located in } \\
\text { the project? }\end{array}$ & & \\
\hline & $\begin{array}{l}\text { Are all the non permanent works dully contemplated at the } \\
\text { project? }\end{array}$ & & \\
\hline & Is there an Integrated Construction Management Plan? & & \\
\hline & Is there an Equipment Maintenance Plan? & & \\
\hline & $\begin{array}{l}\text { Are the equipment on site dimensioned to work with possible } \\
\text { adverse weather conditions? }\end{array}$ & & \\
\hline & $\begin{array}{l}\text { Does the contractor/sub-contractor have experience in the type of } \\
\text { construction technique adopted at the project? }\end{array}$ & & \\
\hline
\end{tabular}


Table 1. Cont.

\begin{tabular}{|c|c|c|c|}
\hline & Hazards & Yes/No & N/A \\
\hline & $\begin{array}{l}\text { Does the contractor/sub-contractor have the means to replace } \\
\text { equipment in case of failure? }\end{array}$ & & \\
\hline & $\begin{array}{l}\text { Does the executing entity have its own means of repairing } \\
\text { equipment locally? }\end{array}$ & & \\
\hline & $\begin{array}{l}\text { Are there cutting tools suitable for the ground listed in the } \\
\text { geotechnical report? }\end{array}$ & & \\
\hline & $\begin{array}{l}\text { Are there cutting tools suitable for all the types of strata to be } \\
\text { intersected? }\end{array}$ & & \\
\hline & $\begin{array}{l}\text { In the event of a punctual extension of the work or the existence of } \\
\text { shifts, are the suitable means of lighting ensured? }\end{array}$ & & \\
\hline & Is there a document describing work procedures? & & \\
\hline & Is there an Inspection and Testing Plan for the works? & & \\
\hline & Is there an Inspection and Testing Plan for the equipment? & & \\
\hline & Is there an Inspection and Testing Sheet for the equipment? & & \\
\hline \multirow{7}{*}{ 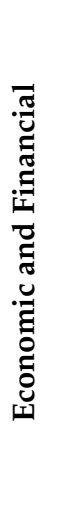 } & Is there a tender budget with $\mathrm{ABC}$ ? & & \\
\hline & Is there an operations budget with $\mathrm{ABC}$ ? & & \\
\hline & $\begin{array}{l}\text { If there are tender and operations budget, are they directly } \\
\text { comparable? }\end{array}$ & & \\
\hline & $\begin{array}{l}\text { If there is an operations budget, is it directly comparable with } \\
\text { accounting? }\end{array}$ & & \\
\hline & $\begin{array}{l}\text { Is there a signed contract reflecting the assumptions of the } \\
\text { geotechnical report and the project? }\end{array}$ & & \\
\hline & Is the performance obtained considered in the production budget? & & \\
\hline & $\begin{array}{l}\text { Is there a clause in the contract to assign the responsibility of } \\
\text { financial losses? Which/To whom? }\end{array}$ & & \\
\hline
\end{tabular}

Table 2. Example of explicit potential hazards checklist for the execution of bored piles (Kelly method) with bentonite suspensions.

\begin{tabular}{ll}
\hline \multicolumn{1}{c}{ Hazards } & Yes/No \\
\hline
\end{tabular}


Table 3. Example of explicit potential hazards checklist for bored piles (Kelly method) using casing.

\begin{tabular}{|c|c|c|c|}
\hline & Hazards & Yes/No & N/A \\
\hline $\begin{array}{l}\bigcup \\
\$ \\
\cup\end{array}$ & Are there any sands with an artesian groundwater level? & & \\
\hline 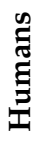 & $\begin{array}{l}\text { Do the site operatives master the skills and knowledge of } \\
\text { construction piles using casing technique? }\end{array}$ & & \\
\hline \multirow{3}{*}{ 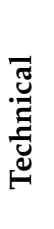 } & Is the casing method the most suitable? & & \\
\hline & $\begin{array}{l}\text { If not, where the designers approached to study/aprove an } \\
\text { alternative? }\end{array}$ & & \\
\hline & $\begin{array}{l}\text { Is the equipment availabe on-site the most suitable to use casing } \\
\text { technique? }\end{array}$ & & \\
\hline
\end{tabular}

Polymer suspensions were not considered because they are not used in Angola due to their high costs. Though there are some other events that could affect the normal progression of the work in sandy soil like the presence of layers or groundwaters with salts and the effect of ties among others, these are not included in this study because there had not been occurrences in the analyzed study cases, making it impossible to calculate their associated likelihood.

Table 4 presents the construction hazards that occurred in 48,061 m of bored piles (Kelly method) using casing or with bentonite support fluids in coarse soils with intercalations of clay layers ( $<1 \mathrm{~m}$ of thickness) in Angola. The considered cases correspond to hazards that were detected and registered on-sites of each of the case studies allowing to calculate the likelihoods of their associated events and determine the inherent risk class.

Table 4. Main potential hazards of bored piles (Kelly method) using casing or with bentonite support fluids at construction stage.

\begin{tabular}{clll}
\hline \multirow{2}{*}{$\begin{array}{c}\text { Execution } \\
\text { Technique }\end{array}$} & \multicolumn{3}{c}{ Construction Hazards } \\
\cline { 2 - 3 } With bentonite & \multicolumn{1}{c}{ Geological } & \multicolumn{1}{c}{ Human } & \multicolumn{1}{c}{ Technical } \\
support fluids & $\begin{array}{l}\text { (ii) Contaminant clay layers } \\
\text { (iii) Brackish or saltwater }\end{array}$ & $\begin{array}{l}\text { (vi) Poor } \\
\text { knowledge of the } \\
\text { technique }\end{array}$ & $\begin{array}{l}\text { (vii) Inadequacy of } \\
\text { the method or } \\
\text { equipment }\end{array}$ \\
\hline Using casing & $\begin{array}{l}\text { (iv) Rock layers or blocks } \\
\text { (v) Sands with artesian } \\
\text { groundwater }\end{array}$ & & \\
\hline
\end{tabular}

\section{Given:}

i. The presence of gravel, pebbles or blocks is a geological hazard in the execution of piles with bentonite suspensions due to two reasons that may occur simultaneously, or independently: the loss of bentonite and/or the incapacity of bentonite to behave as a thixotropic fluid and form a cake, ensuring the stability of the bored walls when crossing these coarse soils.

ii. Clay interception is a geological hazard in bored piles with bentonite support fluids whenever these soils contaminate the mud (by addiction), causing its density to increase and making impossible to pump the mud to desanding and/or decreasing the mud thixotropy.

iii. The presence of brackish or saltwater is a geological hazard in piling with bentonite slurry since these salts will react with bentonite suspension inducing flocculation and affecting the mud thixotropy negatively. 
iv. The existence of cemented layers (rocks) or blocks is a geological hazard in the execution of bored piles with casing when their strength prevents the casing progression.

v. Artesian groundwater levels in sands are a geological hazard in the execution of bored piles with casing when it causes the coarse soils to ascend inside the casing, preventing their cleaning.

vi. The site operatives often lack skills in construction of bored piles with casing or bentonite support fluids giving rise to quality problems of the pile executed.

vii. For both types of aforementioned bored pile technics, the inadequacy of the method or equipment used is a technical hazard that manifests itself whenever the equipment or method available for the work is not suitable for the site or when the equipment is sub/oversized for the work to be carried out, negatively influencing the budget.

Any of these hazards will be associated at least with one triggering event that has a given probability of occurring. However, and in the specific case of construction of bored piles (Kelly method), there are no published tables for those probabilities. Thus, the concept of likelihood was used in this research, which mathematically describes the conditional probability of a result face to a data set, that in this study is the number of occurrences verified in $24,903 \mathrm{~m}$ of executed piles.

The likelihood of events that trigger these hazards must be assessed as well as the associated damages by applying event tree analysis to evaluate the risk magnitude (risk analyses and evaluation). At present and until the realization of databases of event occurrences in piling, as it has already been done for tunnels or dams, each technician/construction company based on their cases and experience, should elaborate the corresponding tables for likelihoods. This is the way used to deal with assumptions. Rozell [35] highlights "this is tricky because there is no systematic list of value assumptions in risk analysis to consult. Even if there was such a list, it would be controversial-value judgments are difficult to recognize". Table 5 thus present the values proposed for bored piles (Kelly method) verified on a set of sites works and intersecting coarse soils in Angola.

Table 5. Likelihood of events occurrences associated with bored piles (Kelly method) in coarse soils with interbedded of clays in Angola.

\begin{tabular}{lcc}
\hline Likelihood & Class & Occurrences in 24,903 m of Piles \\
\hline Very common & 5 & $>40$ \\
\hline Frequent & 4 & 20 a 40 \\
\hline Occasional & 3 & 10 a 20 \\
\hline Rare & 2 & 4 a 10 \\
\hline Very rare or null & 1 & $<4$ \\
\hline
\end{tabular}

The definition of the number of events to which a given probability is possible will designate the above-mentioned likelihood class (5 to 1 ) in a purely quantitative way. This study deals with construction risks, $R$, by calculating their magnitude (Equation (1)) by multiplying the likelihood of the occurrence of a consequence, $v$, by the economic impact of the inherent damage (or consequence) class, $d$.

$$
R=v \times d
$$

A classification based on the economic accounting of damages was introduced (Table 6), but it may differ depending on the company in which they are used. The values and classification of the consequences adopted are based on the real cost percentage of the associate mitigation or corrective solution adopted at the several case studies and relative to the construction cost, which is the monetary value of the execution of the work, without any de- 
viations from the tender budget. Experience shows that there are companies that calculate costs based on factual cost and others that evaluate them as a percentage of production.

Table 6. Consequence classes of financial impact according to the percentage (\%) of the impact on the construction cost.

\begin{tabular}{cc}
\hline Construction Cost (\%) & Consequence Classes \\
\hline$>100$ & 6 \\
\hline 80 to 100 & 5 \\
\hline 60 to 79 & 4 \\
\hline 40 to 59 & 3 \\
\hline 20 to 39 & 2 \\
\hline 1 to 19 & 1 \\
\hline
\end{tabular}

Table 7 lists the potential consequences and their economic impact for bored piles (Kelly technique) using casing and the potential consequences identified for bored piles with bentonite mud include Table 8 . When the percentage of cost covers more than one class of consequence, one should go for the worst-case scenario, according to Cox [36], to keep with the risk matrix weak consistency (Table 9), as low as it is reasonably possible. The consequences with economic impact listed in both Tables 7 and 8 and their meaning are the following ones:

(i) "Drilling halted": when changing the construction method or adjusting or replacing the equipment, the work must be stopped.

(ii) "Sand inclusions" can occur while concreting when the sand lodged inside the casing is not completely dragged out in front of the concrete, thus forming sand inclusions in the pile. This situation can only be verified after the end of the pile construction through quality control by pile dynamic integrity tests (PIT), sonic tests or core drilling.

(iii) "Impediment to construction": the construction process must be stopped until new solutions are approved.

(iv) "Rebar uplift": while concreting operation, at the removal of casing sections, the reinforcement rises with the upward movement of the casing.

(v) "Loss of productivity": production yield is lower than estimated.

(vi) "Incomplete or non-existent registration of the event occurred": no document is drawn up for the events that gave rise to the consequence.

(vii) "Lost of a pile": when element collapses after completion of excavation.

(viii) "Collapse of the pile" when the pile collapses while excavating.

(ix) "Impediment or difficulty in mud pumping": bentonite support fluid becomes more viscous making it difficult or preventing its pumping for recycling.

(x) "Concrete overconsumption" the volume of concrete used in concreting of the pile is higher than that considered in the tendering budget.

In theory, the economic implication is already contemplated in the definition of risk, since it is the value of the consequence; however, the risk evaluated corresponds, in this approach, to four risk magnitudes that are defined according to fundaments of the Project Management Institute [37] applied to bored piles (Table 9): acceptable; significant; high and intolerable. 
Table 7. Consequence classes of financial impact for bored piles (Kelly method) using casing.

\begin{tabular}{lcc}
\hline \multicolumn{1}{c}{ Damage } & $\begin{array}{c}\text { Construction Cost } \\
\mathbf{( \% )}\end{array}$ & Consequence Classes \\
\hline (i) Drilling halted & 65 to $>100$ & 6 \\
\hline (ii) Sand inclusions & 20 to 100 & 5 \\
\hline (iii) Impediment to construction & 50 to 85 & 4 \\
\hline (iv) Rebar uplift & 25 to 65 & 1 \\
\hline (v) Loss of productivity & 1 to 10 & \\
\hline $\begin{array}{l}\text { (vi) Incomplete or inexistent } \\
\text { register of an event occurred }\end{array}$ & & \\
\hline
\end{tabular}

Table 8. Consequence classes of financial impact for bored piles (Kelly method) with bentonite support fluids.

\begin{tabular}{lcc}
\hline \multicolumn{1}{c}{ Damage } & $\begin{array}{c}\text { Construction Cost } \\
\mathbf{( \% )}\end{array}$ & Consequence Classes \\
\hline (i) Drilling halted & 75 to $>100$ & 6 \\
\hline (vii) Lost of a pile & 100 & 5 \\
\hline (iii) Impediment to construction & 20 to 75 & \multirow{2}{*}{3} \\
\hline (viii) Collapse of the pile & 40 to 55 & \multirow{2}{*}{2} \\
\hline (ix) Impediment or difficulty in mud pumping & 15 to 35 & \multirow{2}{*}{1} \\
\cline { 1 - 2 } (x) Concrete overconsumption & 10 to 25 & \\
\hline (v) Loss of productivity & 1 to 15 & \\
\hline (vi) Incomplete or inexistent register of an & 1 to 10 & \\
event occurred & & \\
\hline
\end{tabular}

Table 9. Magnitude classification of singular risks.

\begin{tabular}{ccccccc}
\hline \multicolumn{7}{c}{ Consequence Classes } \\
\hline Likelihood & $\mathbf{1}$ & $\mathbf{2}$ & $\mathbf{3}$ & $\mathbf{4}$ & $\mathbf{5}$ & $\mathbf{6}$ \\
\hline 1 & 1 & 2 & 3 & 4 & 5 & 6 \\
\hline 2 & 2 & 4 & 6 & 8 & 10 & 12 \\
\hline 3 & 3 & 6 & 9 & 12 & 15 & 18 \\
\hline 4 & 4 & 8 & 12 & 16 & 20 & 24 \\
\hline 5 & 5 & 10 & 15 & 20 & 25 & 30 \\
\hline \multicolumn{7}{r}{} \\
\cline { 2 - 7 } & Acceptable & Significant & Risks & High & & Intolerable \\
\hline
\end{tabular}

Afterwards, the site project manager must perform the ABC cost control that will substantiate his decision making according to two risk scenarios: (i) incur, or (ii) mitigate the risk. If it is decided to incur the risk, two scenarios may occur at site: (i) nothing happens (no occurrences), the pile work is successfully concluded without any deviation to the work budget; or (ii) an event arise with the subsequent deviation to the construction budget. In this last scenario, a best way-out [32] solution based on a set of proposed actions to eliminate or mitigate the risk should be used to evaluate the corrective measures to be implemented and the associate costs. On the other hand, if one chose to mitigate the risk, one would also have two alternative settings like those related to incurring the risk, but the difference would be the decrease in the likelihood of an occurrence (decision on whether to use a mitigate measure or a corrective measure). Nevertheless, economic cost is never considered in an explicit, clear, and valued way as a decision-making tool as it is proposed hereafter. 
In the presence of an acceptable risk, but with a high likelihood, it is advisable to examine the economic implication of a set of piles. Economic classifications were attributed to the same risk nomenclatures at four levels to obtain ease of reading, comparison and understanding. These levels should be identified by the economic margin of the projects under consideration and, where the margin is consumed, with the economic implication, and the risk should be considered intolerable. However, the concept of "intolerable" depends on the internal policies of each company.

For example, consider a set piles where the bored walls present small collapses while drilling, but stays stable for concreting. This event often happens on clayey sands when drilling with muds of controlled density, namely with bentonite, on diameters larger than $600 \mathrm{~mm}$. This risk is acceptable at the construction stage and can induce an overconsumption of concrete. However, when considering the whole project, this can have a considerable impact on the budget and may result in an intolerable economic implication. Despite the risk being technically acceptable for a single pile, it should be mitigated or even eliminated for the overall set of similar piles due to economic reasons. The construction risk analysis without the inherent cost controls with budget forecast for the complete construction work, would not give the necessary emphasis to such a situation and would lead to a financial loss.

Thus, it is proposed a methodology that will link cost control with risk management in an interactive manner with planning at construction stage, enabling decisions also based on economic implications with immediate forecasts. Figure 3 shows this dynamic for bored piles (Kelly method) that includes Figure 1 and the associated ABC cost control, which involves checking the magnitude of the risk and consequent updating of the construction budget. Tender budget deviations and the economic implications should always be examined before decision making: (i) take the risk, (ii) eliminate it or (iii) mitigate it. The work must be re-budgeted, according to the decision made. Then, the risk interaction process resumes. Using a continuous interaction, as presented, in real time requires that the work (pilling) be accompanied by a project and contract that accepts progressive modifications as suggested by Eurocode 7 [38] and Spross [39].

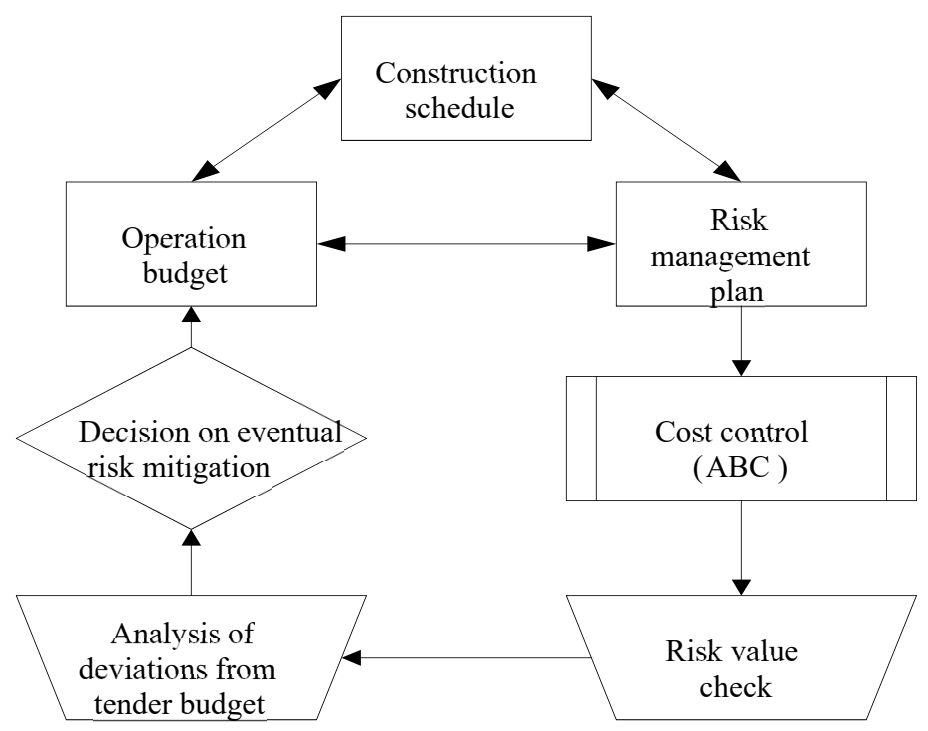

Figure 3. Interaction between the economic implication of risk and the interdependence of construction planning, budget and risk management.

This methodology was tested successfully at twelve bored piles site works in Angola, as shown in the two case studies presented hereafter, where it was used at the beginning and while constructing in Luanda (Angola), a nonseismic region. 


\section{Application of the Methodology at Two Site Works in Luanda (Angola) \\ 4.1. Case Study 1-Talatona Church}

This example of implementation of the methodology corresponds to the construction of foundations to a building of about $2000 \mathrm{~m}^{2}$ that had between one and three floors located in Luanda (Angola), and having no confinements surrounding the site (Figure 4). The ground was made up of coarse sandy soils with some clay layers intercalations (less than $1 \mathrm{~m}$ in thickness), and no groundwater table was detected during the project. The report endorsed two types of piles diameter, $600 \mathrm{~mm}$ and $800 \mathrm{~mm}$, with lengths varying between 11.5 and $17.0 \mathrm{~m}$.

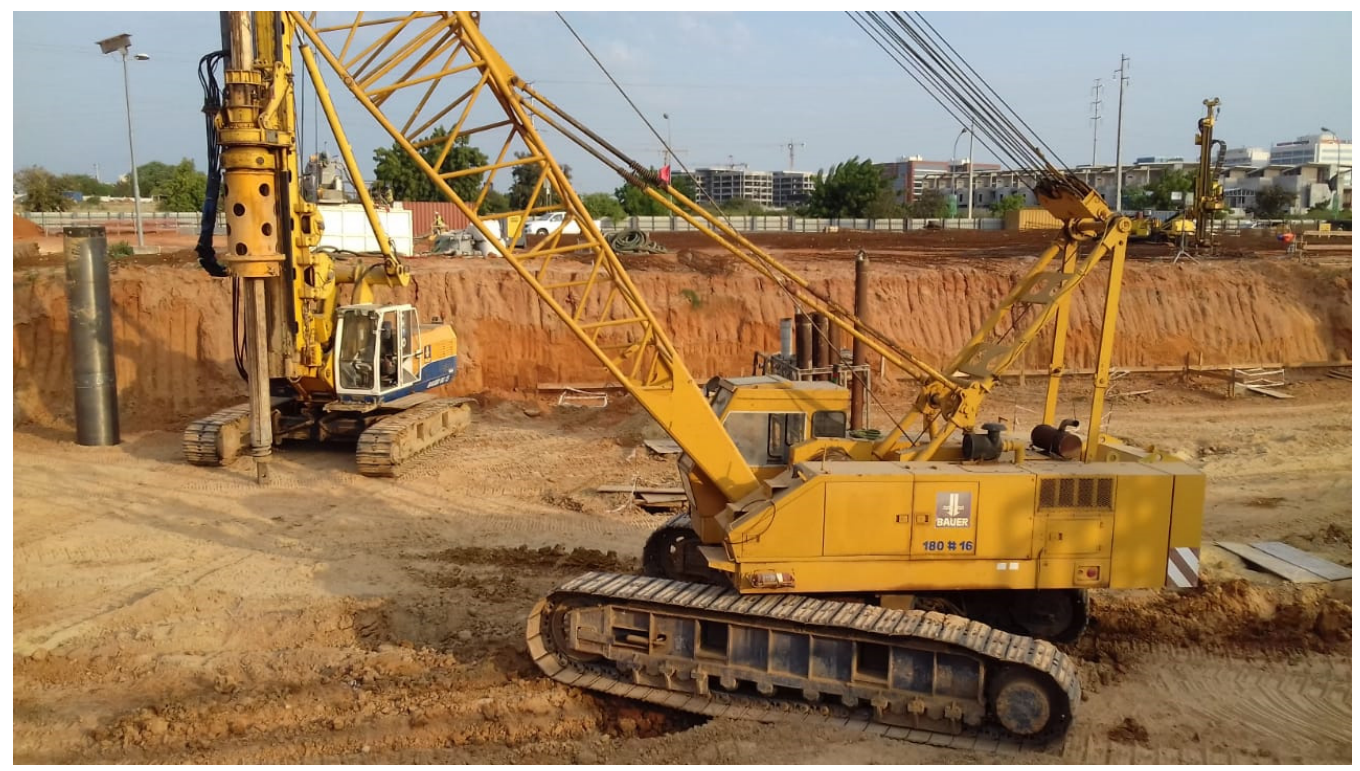

Figure 4. Talatona church site equipment view.

This case refers to the subcontract for 54 piles, $800 \mathrm{~mm}$ in diameter and unfold during a drought season in 2017. The work was carried out with a Kelly bar drilling machine of 15 Ton of torque [40] and all the elements of the work are summarized in Table 10. The contracted deadline for the execution of the piles was 13 working days.

Table 10. Resume of pile works performed at Benfica building.

\begin{tabular}{clc}
\hline Equipment Mobilization & \multicolumn{1}{c}{ Mobilization/Demobilization(un) } & \multicolumn{1}{c}{$\mathbf{1}$} \\
\hline \multirow{3}{*}{ Piles executed } & Total of piles (un) & 54 \\
\cline { 2 - 3 } & Total length of piles (m) & 817.00 \\
\cline { 2 - 3 } & Total drilling with bentonite mud (m) & 481.00 \\
\cline { 2 - 3 } & Daily drilling with bentonite mud average (m) & 43.73 \\
\cline { 2 - 3 } & Total drilling using casing (m) & 336.00 \\
\cline { 2 - 3 } & Daily drilling using casing average (m/day) & 35.37 \\
\hline \multirow{2}{*}{ Cost control } & Total margin (\%) & 29.17 \\
\cline { 2 - 3 } & Tendering margin (\%) & 34.97 \\
\hline
\end{tabular}

\subsubsection{Potential Hazards Identification and Associated Risk Analyses}

According to the general contractor information, the soil was loose and thus previous excavations and piles tend to fall while concreting. Prior to the work start, the production team, coordinated by the first author, carried out the hazard checklists (Tables 1 and 3), not detecting any high or intolerable risk for drilling with Kelly method using casing; the necessary equipment was mobilized to the site. 
During the execution of the work, it was found that the information provided by the general contractor was inaccurate and it was realized that the soil did not collapse according to the information received. Therefore, a new checklist was made, and it was identified the "Inadequacy of method or equipment" hazard (Table 4, vii) which generated the event "Impediment or decrease of drilling performance".

\subsubsection{Risk Analyses and Evaluation}

A risk assessment was then performed corresponding to the exchange of drilling technique of bored piles (Kelly method) using casing to bentonite or polymer support fluids, which would allow better performance for the conditions at the site, and which matches the event tree of Figure 5.

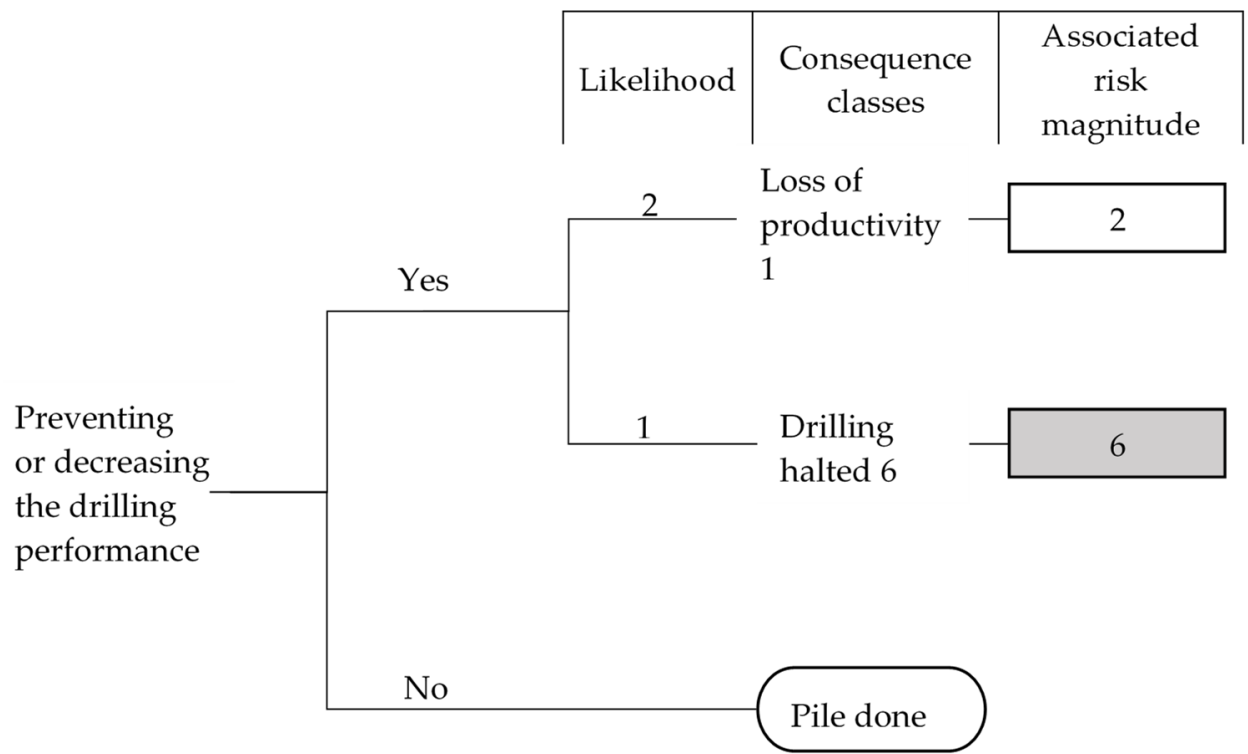

Figure 5. Bored piles (Kelly technique) using casing: event tree for technical hazard "Inadequacy of the method or equipment".

The event trees used are a little different from the ones applied in the tunnels or dams. It starts by defining the event that could generate the consequence. The figure consists of three columns for the event "Preventing or decreasing the drilling performance": "Likelihood"; and inherent "Consequence" and "Associated risk magnitude". Each of the listed consequences is already accompanied by their classes (Table 9). The risk magnitudes are obtained by Equation (1).

For the event "Impediment or decrease in drilling performance", the likelihood is 2 (Table 5), and the associated damage "Loss of productivity" is labeled as class 1 (Table 7, v); but likelihood is 1 (Table 5) for the inherent consequence of "Drilling halted", classified as 6 (Table 7, i); the risk magnitudes (Table 9) are classified as tolerable-2 and significant- 6 , respectively.

In this case, the "drilling halted" was not detailed because the likelihood was 1, even for a significant risk, but the stopped work would happen only at a single pile and not in all of those that were selected to incur this risk. Based on the scheme of Figure 5, the risk register for this work is presented in Table 11, that states that there was a construction technical hazard of "Inadequacy of the equipment" (Table 4, vii) that may cause an event of "decreasing drilling performance" in which the likelihood of the occurrence was rare, value 2 , and the associate consequence would be the "loss of productivity", value 1; it was obtained an acceptable risk class-2. 
Table 11. Example of risk register for the change of executive process for Benfica building bored piles.

\begin{tabular}{ccccc}
\hline Hazard & Event & Likelihood & Consequence & Risk Magnitude \\
\hline $\begin{array}{c}\text { Technical: } \\
\text { Inadequacy of } \\
\text { equipment }\end{array}$ & $\begin{array}{c}\text { Decreased } \\
\text { drilling } \\
\text { performance }\end{array}$ & 2 (Rare) & $\begin{array}{c}1 \text { (Loss of } \\
\text { productivity) }\end{array}$ & 2 (Acceptable) \\
\hline
\end{tabular}

\subsubsection{Contingency Measures and Discussion}

In line with these results and considering that only technical risk analysis for a single pile would be done, it was found that it would take about 26 days (based on the first 10 days average performance of the construction work) exceeding the planned 13 days. However, when the control of costs and the forecast completion of work with an "acceptable" risk was extended to all the piles, it was pointed out a deviation from the planned budget. Therefore, it was decided to change the construction process based on the risk pile assessment and how the execution of all bored piles with casings would affect the final budget-it was forecasted a diminished margin of profit provided by the cost control carried out. The solution adopted was the construction of the remaining piles with bentonite support fluid. The work was completed with 23 bored piles with casing and 31 piles using bentonite support fluids, all $800 \mathrm{~mm}$ in diameter.

Figure 6 shows that a productivity growth occurred on the 10th day of work: $34 \mathrm{~m}$ of piles with casing done in $6 \mathrm{~h}$ against $34 \mathrm{~m}$ of piles using bentonite muds built in $3 \mathrm{~h}$, after implementation of the change in piling execution technique. Since this change ought to be previously approved by the client, it was only implemented at the 10th day. The daily average of piles construction was $33.6 \mathrm{~m}$ /day and went to $64.4 \mathrm{~m} /$ day. Nevertheless, the work ended with an operational margin lower than the tendering one of about $4 \%$, which would have been considerably higher if it would had not been decided to change the piling process. The final average of piles construction was $47.3 \mathrm{~m} / \mathrm{day}$, and the contract were completed in 17 working days. If the complete risk assessment had not been implemented and considering that the initial mean of piles construction was $33.6 \mathrm{~m} /$ day, it would have taken 25.5 working days to complete the work, which would have amounted to an additional $50 \%$ of the time of the contract.

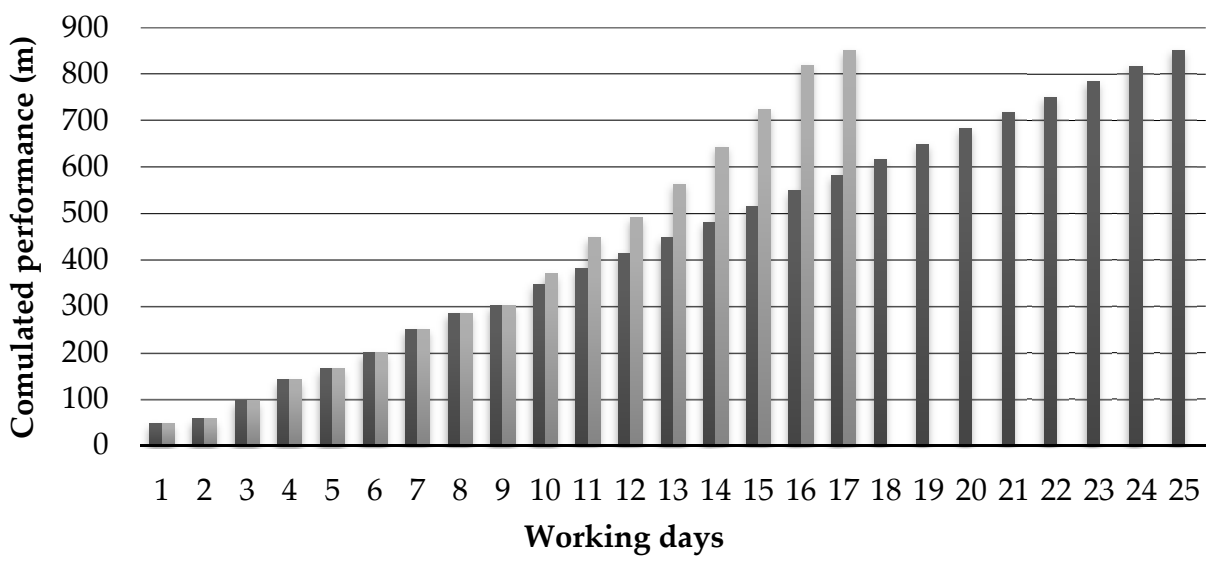

Comulated performance without technique change (forecast from the tenth day based on the average performance from $\mathrm{ABC}$ cost control)

Figure 6. Production evolution graph on site at Talatona, Luanda.

In synthesis, it can be considered that if risk management had not been implemented, the following would have happened:

- With the application of the proposed methodology, the work took 17 days, if risk management had not been applied it would have taken 25.5 days, e.g., 1.5 more time. 
- The additional 7.5 days would correspond to a direct increase in cost, except for included material costs for works where there is a $20 \%$ increase (value obtained from the accounting).

- Such increase would have raised the cost $(c)$ in the contract of the first 17 days $\left(c_{17}\right)$. The cost of the work for the 25.5 days $\left(c_{25.5}\right)$ would be $\left(c_{25.5}\right)=1.4 \times\left(c_{17}\right)$.

- Using the absolute values of the invoicing (I) and the costs (c) of the accounting, it would have the final margin for 25.5 days $\left(\mathrm{mf}_{25.5}\right)=\mathrm{f}-1.4 \times\left(\mathrm{c}_{17}\right)$, which corresponds to $\left(\mathrm{I}-1.4 \times\left(\mathrm{c}_{17}\right)\right) / \mathrm{I}=0.83 \%$.

One can conclude that if this methodology had not been applied, the result of the work would have been less $0.83 \%$, which was much lower than the one obtained.

\subsection{Case 2-Viaduct Nelito Soares}

The second selected case study refers to the piling construction for viaduct located on the east exit of Luanda, that was also supervised by the first author. The viaduct had 144 piles with lengths between $26.5 \mathrm{~m}$ and $27.5 \mathrm{~m}$ in sands with some interbedded clays with less than $1 \mathrm{~m}$ in thickness. The bored piling construction technics foresee the use of bentonite supported fluids and casing with Kelly bar equipped drilling machines (Figure 7), of 15 and 28 Ton of torque [40,41].

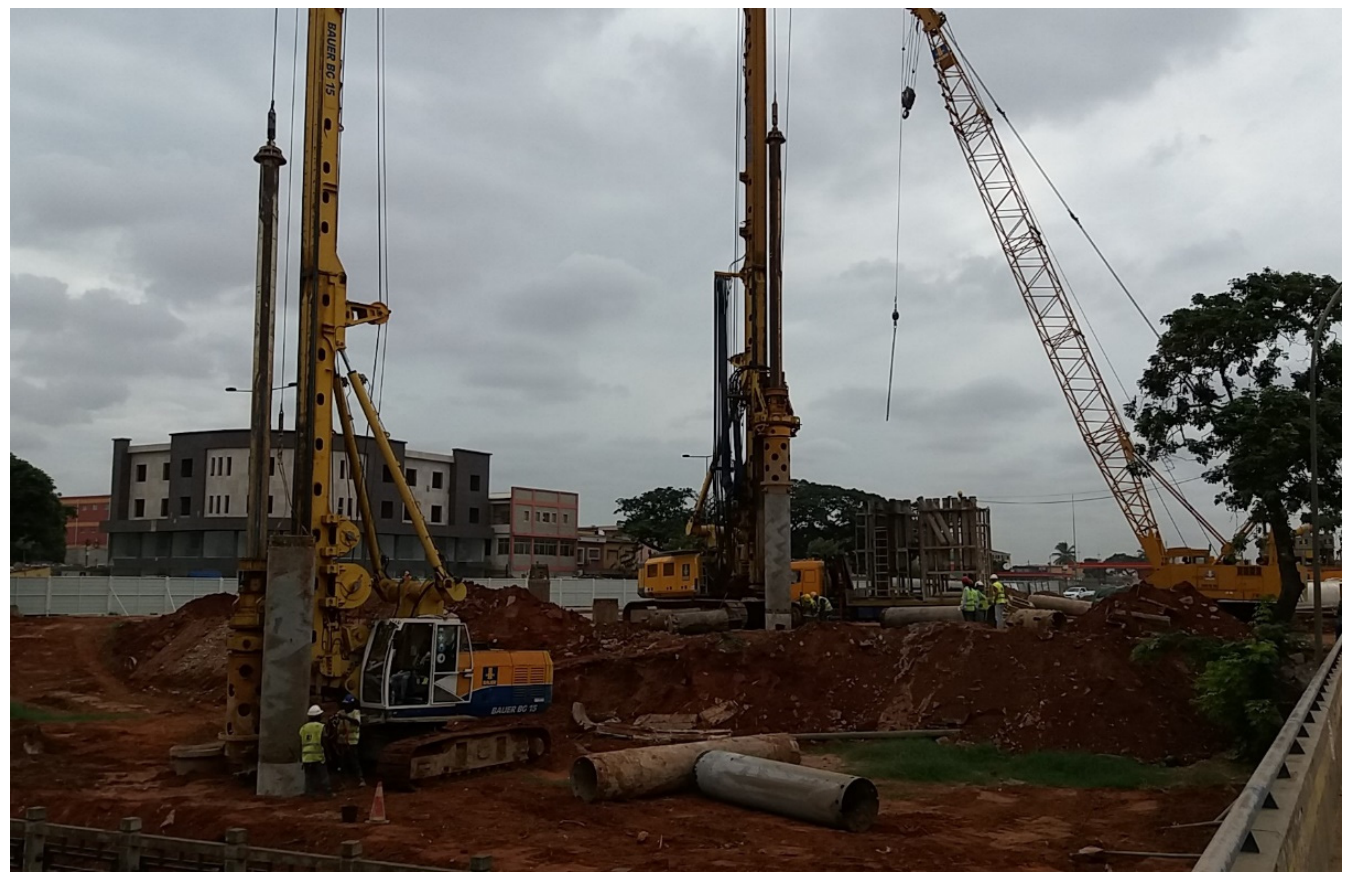

Figure 7. Main view of the Nelito Soares viaduct site and equipment.

This site was confined on all fronts by the Luanda-Catete road, which is the busiest road in Angola, with more than 1,000,000 commuters per day. During the contract, the general contractor had to detour traffic for three times. This situation conditioned both the work, due to the constant movement of equipment, and the mobility of the commuters. However, they were the client's responsibility, which is why they are not discussed hereafter. The work took place between February and May 2017.

The main challenge in this work was the execution time. The deadline to construct $3746 \mathrm{~m}$ of piles in 3 months, was very tight to be carried out using cased piles. The project defined that the piles should be cased in the vicinity of an existing buried conduit and bored with bentonite muds outside the influence area of this infrastructure. The proposed methodology was implemented by the foundations sub-contractor since the beginning of the piling works, but at the first two piles some sand balls inclusions were detected in the shaft of the piles (Figure 8). This situation was promptly managed with the risk assessment. 


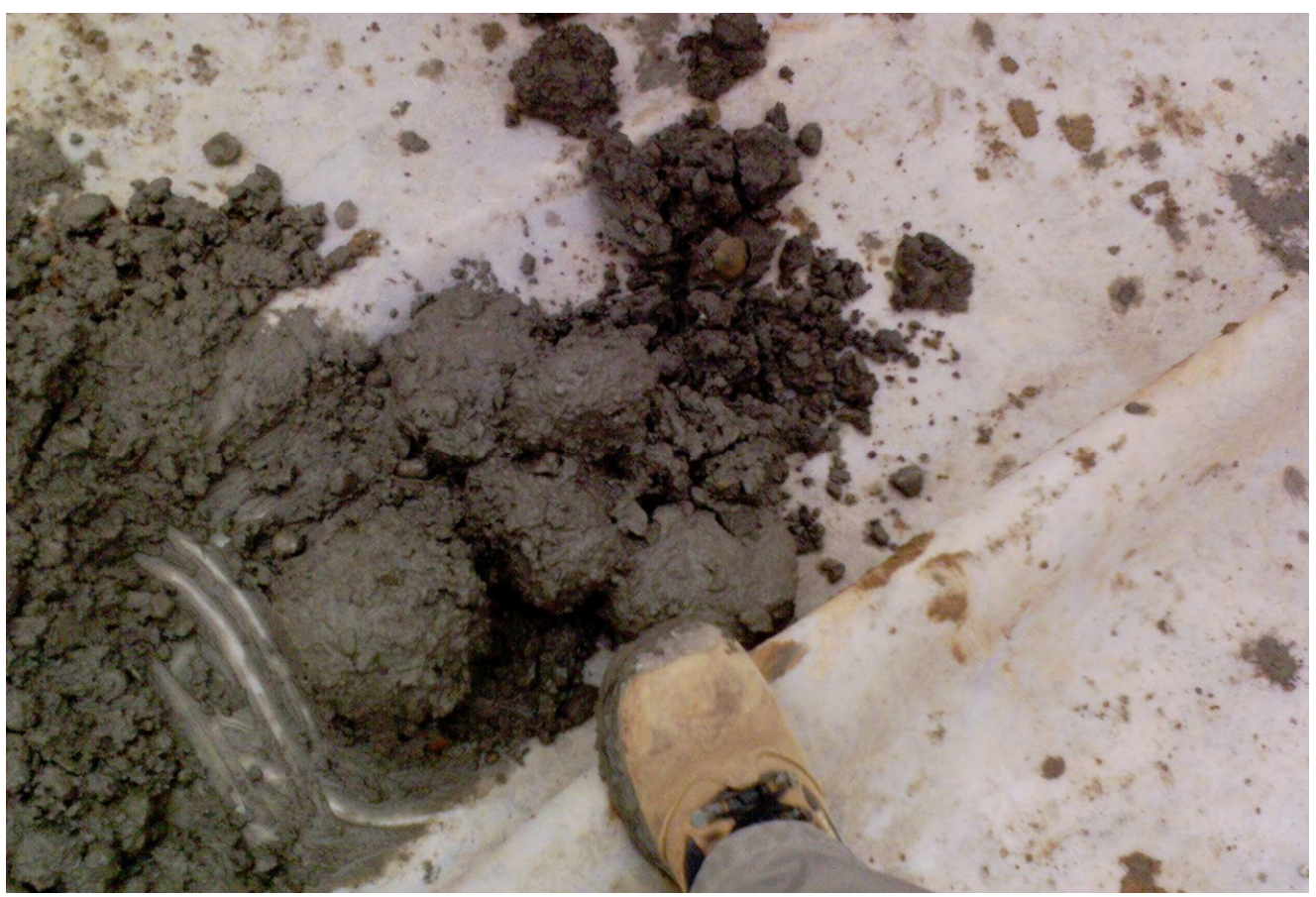

Figure 8. Detail of the sand balls covered with concrete (scale: size 5 boot).

The soils intercepted by the drilling were sands and silty sands with increased density in depth. The groundwater table was found between 8 and $10 \mathrm{~m}$ of depth, depending on the level drilled.

Table 12 summarize the works performed.

Table 12. Resume of pile works performed at viaduct Nelito Soares, Luanda.

\begin{tabular}{clc}
\hline Equipment Mobilization & \multicolumn{1}{c}{ Mobilization/Demobilization(un) } & \multicolumn{1}{c}{$\mathbf{2}$} \\
\hline \multirow{4}{*}{ Piles executed } & Total of piles (un) & 144 \\
\cline { 2 - 3 } & Total length of piles $(\mathrm{m})$ & 3839.85 \\
\cline { 2 - 3 } & Total drilling with bentonite mud (m) & 2549.70 \\
\cline { 2 - 3 } & Daily drilling with bentonite mud average (m) & 35.03 \\
\cline { 2 - 3 } & Total drilling using casing $(\mathrm{m})$ & 1243.45 \\
\cline { 2 - 3 } & Daily drilling using casing average (m/day) & 35.03 \\
\hline \multirow{2}{*}{ Cost control } & Total margin $(\%)$ & 39.48 \\
\cline { 2 - 3 } & Tendering margin $(\%)$ & 30.12 \\
\hline
\end{tabular}

\subsubsection{Potential Hazards Identification and Associated Risk Analyses}

As mentioned before, it was verified the presence of sand balls with diameters between 0.10 and $0.15 \mathrm{~m}$, flowing to the pile top, while cleaning the concrete. Apparently, there was no reason for this, and the foreman did not register it due to the lack of explanation for it. Using similar checklists to the ones exemplified on Tables 1 and 2, it was determinate that this was an human hazard-"Poor knowledge of the technique" (Table 4, vi).

\subsubsection{Risk Analyses and Evaluation}

The event tree developed follows a similar approach as the one of Figure 5 but applied to the specific occurrence. This human hazard induces the event of "Unable to solve the events" that could induced two kind of damages with likelihoods (Table 5) of 2 and 3, respectively: "Lost of productivity" and/or "Incomplete or inexistent register of an event 
occurred" (Table 7, v and vi, respectively), both labelled as class 1 . The risks magnitudes (Table 9) are considered as acceptable (classes 2 and 3) for one single pile (Figure 9).

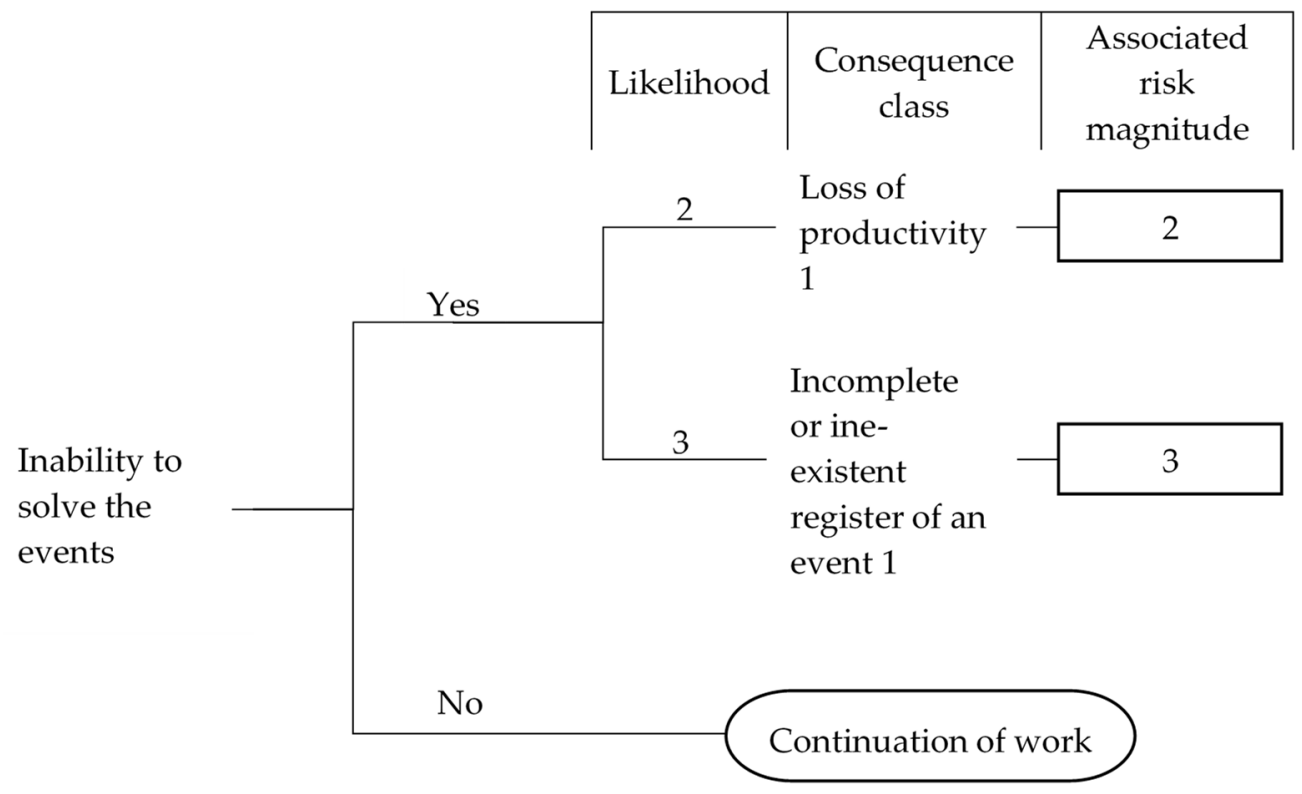

Figure 9. Bored piles (Kelly technique) using casing: event tree for human hazard "Poor knowledge of technique".

Table 13 presents the risk register for this work.

Table 13. Example of risk register for the change of executive process for bored piles at Nelito Soares viaduct.

\begin{tabular}{ccccc}
\hline Hazard & Event & Likelihood & Consequence & Risk Magnitude \\
\hline $\begin{array}{c}\text { Poor } \\
\text { knowledge of } \\
\text { the technique }\end{array}$ & $\begin{array}{c}\text { Unable to } \\
\text { solve the } \\
\text { events }\end{array}$ & $\begin{array}{c}\text { (occasional) or } \\
2\end{array}$ & $\begin{array}{c}\text { (Loss of productivity } \\
\text { and/or Incomplete or } \\
\text { inexistent register of } \\
\text { the event) }\end{array}$ & 3 (Acceptable) \\
\hline
\end{tabular}

\subsubsection{Contingency Measures and Discussion}

It was decided to sustain the risk and continue with the contract. The risk assessment was not preceded by an immediate action. Hereupon, a best way-out solution was needed. The occurrence was a consequence of "Incomplete or inexistent register of an event" but the alert for this situation led the site project manager to investigate the matter. It was concluded that the underlying motive was the removing of the concrete column with excessive speed, which caused a suction effect of the sand into the pile, resulting in the aforementioned sand balls in the shaft of the piles. However, as it was made the ABC cost control, it was found that this could lead to a deviation on the budget due to the eventual pile repair. Therefore, it was decided that the site operatives needed extra training on the subject, which was implemented and the damage stop occurring.

Due to this situation, $20 \%$ of the piles were tested with cross-hole tests and the remaining $80 \%$ with sonic tests, all of them with success. The timely risk assessment also allowed the work to be concluded with a positive deviation from the budget.

Assuming that the risk was not managed, but that the damage of the sand balls described above would be detected at the construction stage, affecting a significative percentage of the work carried out-for example, it will be considered $10 \%$; there would have been a direct increase of $10 \%$ in the costs. With the final profits and construction costs, 
obtained from accounting adding the cost by $10 \%$, it is possible to extrapolate that the margin of the cost of work without risk management would be $32.92 \%$, which would be lower than the one obtained $39.01 \%$.

Figure 10 compares the (tender, operation and without risk management) margins results, in percentage terms, of the 12 case studies analyzed during the research (A-J, including the two cases previously detailed) showing the positive financial outcomes due to risk management implementation at the construction stage: the margins tend to be significantly positive and higher than the ones that would probably be obtained if the proposed risk management was not implemented.

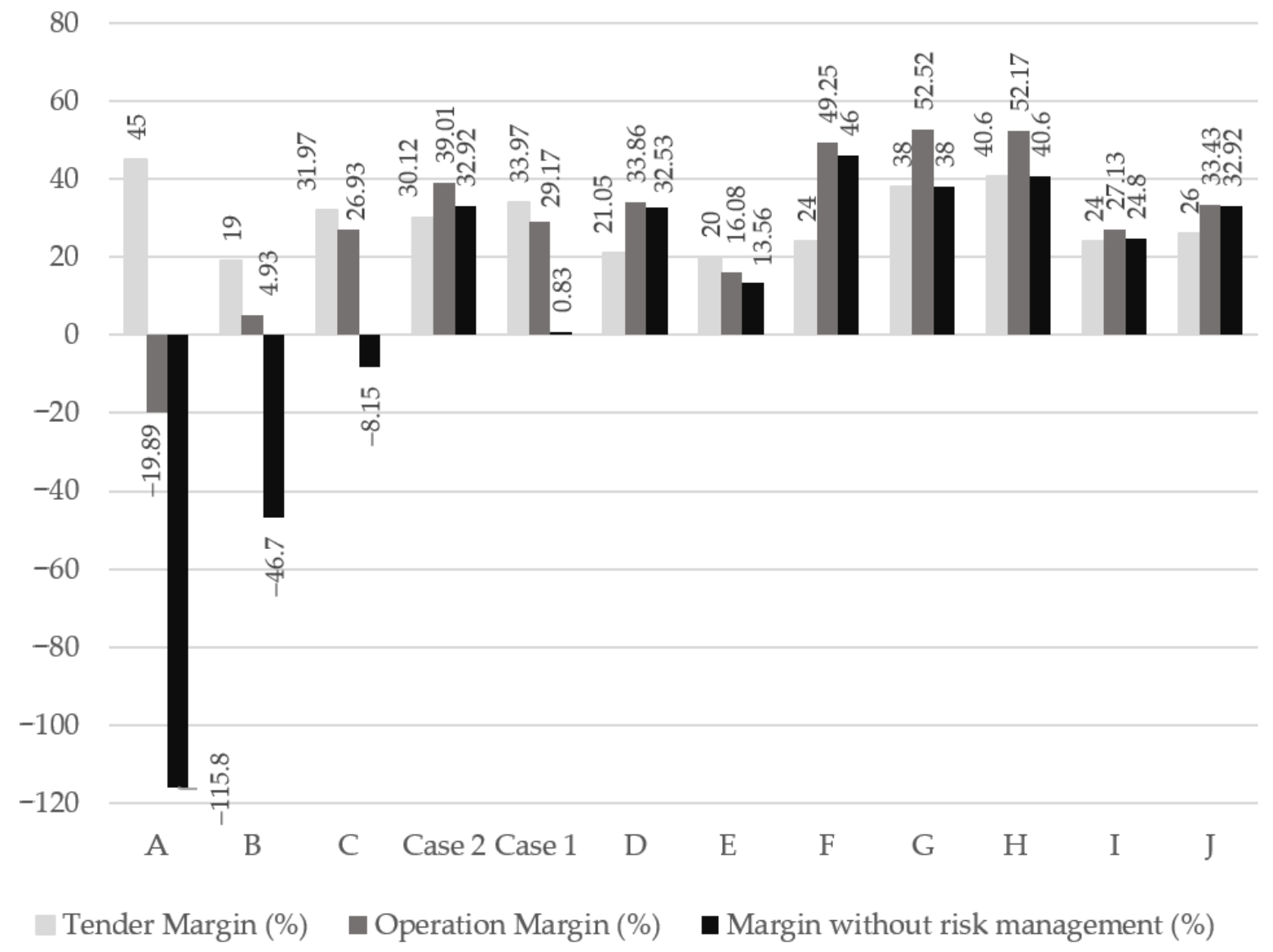

Figure 10. Margins (in percentage terms) of the 12 case studies of bored piles construction in Angola where the proposed methodology was implemented and comparison with forecast of piling construction costs without risk management.

\section{Conclusions}

The construction of bored piles in coarse soils, whether using cased or with bentonite support fluids, has several uncertainties that are difficult or impossible to determine before work begins. They may be of geological, geotechnical, human, or technical origin; therefore, a risk management at the construction stage is essential for the effective sustainability of those works. In fact, the emphasis should be placed on the need for risk management and not on the size of the project.

In this context, a construction risk management methodology, based on real costs and implemented in real time, is presented for the first time. This methodology is based on the construction of simplified event trees, and cost control based on ABC activities that will allow the verification of the accounting of costs by nature and the risks of each activity, separately, in real time, and forecasting the final costs of the work based on the eventual mitigation decisions adopted. The proposed methodology is different from any other presented before since: (i) it is the first time that potential damages likelihoods are 
evaluated by analyzing the number of events that occurred at real construction sites and involving only coarse soils; (ii) it was validated at the construction of more than 48,000 m of bored piles in sandy soils in Angola, proving its versatility and ease of implementation. Additionally, as seen in the two case studies presented, it provides economic values to select between corrective measures whenever they must be implemented by the site project manager.

At the construction stage of piles, there is no doubt in the procedure to implement risks classified as high or intolerable, as the recommended contingency measures should be applied. However, when the risks are acceptable or significant, the decision on mitigation can be doubtful. In this way, the application of cost control with forecast of the impact on the final budget due to the actions to incur or mitigate the risks can provide the site project managers with a combined tool to maximize the performance during construction. From the above, it is concluded that the proposed method, applied to bored piles (Kelly technique) can alert to an unacceptable increase in costs considering the set of piles to execute, which implies need to approve mitigating actions to be taken to ensure a final margin of profit whenever the risk considered for a single pile is acceptable or significant.

The two case studies selected to test this methodology show its ability to provide those responsible for the work (site project managers) with the ability to manage in real time the effectiveness of the measures to be implemented, choosing the corrective measures based on their economic impact. By implementing this type of approach, site project managers will have a tool to assess the risk and cost of incurring it in real time, contributing to better and more efficient decisions, particularly if this analysis is automated at each company; for example, using neural networks, and if the calculation of the probabilities is based on a database of the various case studies at the company's curriculum. This is an important alternative to the traditional approach of developing potential risk context profiles built upon the practice of a set of experts.

Author Contributions: Conceptualization, P.M. and P.F.S.; methodology, P.M. and P.F.S.; validation, P.M.; formal analysis, P.M. and P.F.S.; investigation, P.M. and P.F.S.; writing-original draft preparation, P.M. and P.F.S.; writing-review and editing, P.M., P.F.S. and F.F.S.P.; supervision, P.F.S. All authors have read and agreed to the published version of the manuscript.

Funding: This research was developed for a Ph.D. dissertation and this publication is supported by the NOVA Ph.D. in Geological Engineering program as well as FCT projects GeoBioTec/NOVA UIDP/GEO/04035/2020 and CERIS UIDB/04625/2020.

Data Availability Statement: This manuscript is a part of a PhD research that will become available at https:/ / run.unl.pt before the end of 2021.

Conflicts of Interest: The authors declare no conflict of interest.

\section{References}

1. Latapie, B.; Alzaylaie, M.; Albelda, R.A.; Sumputh, J.; Samra, M.A. A review of piling industry practices in Dubai, UAE: Proposed UCS-based correlations. Geotech. Res. 2019, 6, 103-129. [CrossRef]

2. Chapman, T.; Marcetteau, A. Achieving economy and reliability in piled foundation design for a building project. Struct. Eng. 2004, 2, 32-37.

3. Hoek, E.; Palmieri, A. Geotechnical risks on large civil engineering projects. In Proceedings of the Keynote address for Theme I-International Association of Engineering Geologists Congress, Vancouver, BC, Canada, 21-25 September 1998 ; p. 12.

4. Chapman, T.J.P. The relevance of developer costs in geotechnical risk management. In Proceedings of the Second BGA International Conference on Foundations, ICOF2008; Brown, M.J., Bransby, M.F., Brennan, A.J., Knappett, J.A., Eds.; IHS BRE Press: London, UK, 2008; pp. 1-26.

5. Hosny, H.E.; Ibrahim, A.H.; Fraig, R.F. Risk management framework for Continuous Flight Auger piles construction in Egypt. Alex. Eng. J. 2018, 57, 2667-2677. [CrossRef]

6. Larisch, M. Risk Management for Piles E Deep Foundations; New Zealand Geotechnical Society: Wellington, New Zealand, 2018.

7. Bles, T.; Al-Jibouri, S.; Van den Abel, J. A risk model for pile foundations. In Proceedings of the 20th International Symposium on Automation and Robotics in Construction ISARC2003 the Future Site, Eindhoven, The Netherlands, 21-24 September 2003; pp. 421-426. 
8. Stuedlein, A.W.; Reddy, S.C. Factors Affecting the Reliability of Augered Cast-In-Place Piles in Granular Soils at the Serviceability Limit State (DFI 2013 Young Professor Paper Competition Winner). J. Deep Found. Inst. 2013, 7, 46-57. [CrossRef]

9. Spross, J.; Stille, H.; Johansson, F.; Palmstrøm, A. On the Need for a Risk-Based Framework in Eurocode 7 to Facilitate Design of Underground Openings in Rock. Rock Mech. Rock Eng. 2018, 51, 2427-2431. [CrossRef]

10. Briaud, J. Failure Has Consequences. Geostrata 2020, 24, 18-20.

11. Lacasse, S. Hazard, Reliability and Risk Assessment -Research and Practice for Increased Safety. In Proceedings of the NGM 2016 Reykjavik 17th Nordic Geotechnical Meeting Challenges in Nordic Geotechnic, Reykjavik, Iceland, 25-28 May 2016 ; pp. 18-42.

12. Reed, J.; Eisenbraun, R.; Wade, D.; Johnson, D.; Martin, J.; Allen, J. Risk Management for Dam Construction; U.S. Society on Dams: Denver, CO, USA, 2017.

13. Schubert, P. Geotechnical Risks in Rock Tunnels; Taylor \& Francis: Aveiro, Portugal, 2004; pp. 53-62.

14. Palmieri, A. Managing financial risk for uncertainty. In Proceedings of the International symposium Practices and Trends for Financing and Contracting Tunnels and Underground Works, Athens, Greece, 22-23 March 2012; pp. 1-15.

15. Nawaz, A.; Waqar, A.; Shah, S.A.R.; Sajid, M.; Khalid, M.I. An Innovative Framework for Risk Management in Construction Projects in Developing Countries: Evidence from Pakistan. Risks 2019, 7, 24. [CrossRef]

16. Ahmed, S.M.; Fayed, A.L. Mitigation of Risks Associated with Deep Excavations: State of the Art Review. Ind. Acad. Collab. 2015, $18,6-8$.

17. Mata, P.; Silva, A.P.; Pinho, F. Risk management procedure in the construction of deep foundations. In Proceedings of the Geotechincs for Sustainable Infrastructure Development; Long, P.D., Ed.; Geotechincs for Sustainable Infrastructure Development: Hanoi, Vietnam, 2016; pp. 261-269.

18. Gransberg, D.D.; Loulakis, M.; Touran, A.; Gad, G.; McLain, K.; Sweitzer, S.; Pittenger, D.; Nova, I.C.; Pereira, R.T.; Pinto-Nunez, M. Guidelines for Managing Geotechnical Risks in Design-Build Projects; Transportation Research Board: Washington, DC, USA, 2018; ISBN 978-0-309-39060-6.

19. Zhang, G.; Wang, C.; Jiao, Y.; Wang, H.; Qin, W.; Chen, W.; Zhong, G. Collapse Risk Analysis of Deep Foundation Pits in Metro Stations Using a Fuzzy Bayesian Network and a Fuzzy AHP. Math. Probl. Eng. 2020, 2020, 4214379. [CrossRef]

20. You, W.; Wang, J.; Zhang, W.; Liu, F.; Yang, D. Construction risk assessment of deep foundation pit in metro station based on G-COWA method. IOP Conf. Ser. Earth Environ. Sci. 2018, 153. [CrossRef]

21. Spross, J.; Olsson, L.; Stille, H. The Swedish Geotechnical Society's methodology for risk management: A tool for engineers in their everyday work. Georisk 2017, 12. [CrossRef]

22. Kalsnes, B.; Vanglelsten, B.V.; Eidsvig, U. Risk analyses in excavation and foundation work. In Proceedings of the 17th Nordic Geotechnical Meeting Challenges in Nordic Geotechnic, Reykjavik, Iceland, 25-28 May 2016; pp. 487-494.

23. Larisch, M.D. Fundamental Mechanisms of Concrete Bleeding in Bored Piles. In Proceedings of the Concrete 2019 Conference, Sydney, Australia, 8-11 September 2019; p. 9.

24. Larisch, M.D. Construction and stability risks for fluid supported deep excavations and their effects on design parameters. In Proceedings of the DFI-PFSF Piling \& Ground Improvement Conference, Sydney, Australia, 23-25 February $2022 ;$ p. 20.

25. Cooper, R.; Kaplan, R.S. Profit Priorities from Activity-Based Costing. Harv. Bus. Rev. 1991, 69, $130-135$.

26. Räikkönen, M.; Molarius, R.; Mäki, K.; Forssén, K.; Petiet, P.; Nieuwenhuijs, A. Creating stakeholder value through risk mitigation measures in the context of disaster management. Infrastructures 2017, 2, 14. [CrossRef]

27. Anjum, R.L.; Rocca, E. From Ideal to Real Risk: Philosophy of Causation Meets Risk Analysis. Risk Anal. 2019, 39, 729-740. [CrossRef] [PubMed]

28. Aven, T.; Renn, O. Improving government policy on risk: Eight key principles. Reliab. Eng. Syst. Saf. 2018, 176, 230-241. [CrossRef]

29. (ISO 31000: 2018). Risk Management Guidelines; IPQ: Caparica, Portugal, 2018.

30. Chapman, T.J.P.; van Staveren, M.T.; Stacey, T.R.; Hellings, J.E. Ground risk mitigation by better geotechnical design and construction management. In Proceedings of the ISGSR2007 First International Symposium on Geotechnical Safety \& Risk, Shangai, China, 18-19 October 2007; pp. 645-656.

31. Mata, P.; Fortuna, C.; Tropa, C.; Gama, C.; Pontes, F.; Silveira, G.; Marques, H.; Quintero, J.; Poças, J.; Guimarães, J.; et al. Portugal First. Entrepreneurs are Needed! "Portugal Primeiro. Empreendedores Precisam-se!"; First.; Edições Sílabo: Lisbon, Portugal, 2011; ISBN 978-972-618-654-0.

32. Powderham, A.; Anthony, O. The Observational Method in Civil Engineering-Minimising Risck, Maximising Economy; Primeira; Taylor \& Francis: Boca Raton, FL, USA, 2021; ISBN 9780429344244.

33. Kaplan, R.S.; Anderson, S.R. Time-Driven Activity-Based Costing. Available online: https://ssrn.com/abstract=485443 (accessed on 13 April 2021).

34. Aven, T. Foundations of Risk Analysis: A Knowledge and Decision-Oriented Perspective; Wiley: Stavanger, Norway, 2003; ISBN 0471495484.

35. Rozell, D.J. Values in risk assessment. In Dangerous Science: Science Policy and Risk Analysis for Scientists and Engineers; Ubiquity Press: London, UK, 2020; pp. 29-56. ISBN 9781911529880.

36. Cox, L.A. What's wrong with risk matrices? Risk Anal. 2008, 28, 497-512. [CrossRef] [PubMed]

37. Project Management Institute. A Guide to the Project Management Body of Knowledge (PMBOK Guide), 6th ed.; Project Managment Intitute: Newtown Square, PA, USA, 2017; ISBN 9781628251845. 
38. BS EN 1997-1:2004 Geotechnical Design; General Rules; British Standard Institute: London, UK, $2004 ;$ p. 168.

39. Spross, J.; Johansson, F. When is the observational method in geotechnical engineering favourable. Struct. Saf. 2017, 66, 17-26. [CrossRef]

40. Bauer Maschinen GmbH. BG 15 H Rotary Drilling Rig; Bauer GmbH: Schrobenhausen, Germany, $2015 ;$ p. 12.

41. Bauer Maschinen GmbH. BG 28 Rotary Drilling Rig; Bauer GmbH: Schrobenhausen, Germany, 2012; p. 12. 